\section{IJLBE \\ 1,2}

156

\title{
The Portuguese building regulation system: a critical review
}

\author{
João Branco Pedro \\ LNEC - National Laboratory for Civil Engineering, \\ OTB Research Institute for Housing, Urban and Mobility Studies, \\ Delft University of Technology, Delft, The Netherlands, and \\ Frits Meijer and Henk Visscher \\ OTB Research Institute for Housing, Urban and Mobility Studies, \\ Delft University of Technology, Delft, The Netherlands
}

\begin{abstract}
Purpose - The purpose of this paper is to provide a critical review of the building regulations and the building control system in Portugal. The organisation, content, and authorities responsible for building regulations are described and an overview is provided of the main stages of the building permit procedure.

Design/methodology/approach - The paper reviews the relevant legal and regulatory provisions and discusses these in the context of commentary published by the various professional associations. Findings - The Portuguese building regulation system has undergone significant changes in the last 20 years. Almost all building regulations currently in force are approved during that period. Some of these are resulted from the implementation of European Directives. Others are changed due to advances in scientific knowledge. Changes in the building control system have mainly been driven by the changing demands of present-day practice, in particular, the absence of sufficient municipal technicians, and the need to expedite building control procedures. The solution has been to move away from public building control and to make private parties responsible for compliance with building regulations. The paper concludes that, although there have been significant improvements in the building regulation system over recent years, two structural problems nevertheless persist. First, building regulations continue to be complex and fragmented, and second the qualifications of technicians are still not adequately defined.
\end{abstract}

Originality/value - A structured overview of the system is provided and the main weaknesses are identified. The proposals for change are suggested by professional associations are summarised, and possible improvements are suggested.

Keywords Buildings, Technical regulations, Control system analysis, Portugal

Paper type General review

\section{Introduction}

The construction sector is strategically important in every country. It provides the buildings and infrastructure on which modern living depends, and impacts greatly on people's safety and health. The sector is also socio-economically important, since it is an important generator of employment and stimulates development in other

International Journal of Law in the Built Environment

Vol. 1 No. 2, 2009

pp. 156-171

(C) Emerald Group Publishing Limited 1756-1450

DOI 10.1108/17561450910974759

The authors thank to Carlos Santos, Fernando Gonçalves, Jeroen van der Heijden, José Nuno Beirão, José Vasconcelos Paiva, Pedro Gouveia, and Sérgio Núncio for giving comments on the draft version of the paper. 
economic sectors. Finally, construction is closely related to sustainable development, as significant quantities of raw materials are consumed by the construction process, and operating the built environment also accounts for a significant proportion of natural resources consumed.

A well-organised building regulation system is therefore crucially important. A building regulation system encompasses building regulations and the building control system. Building regulations set down baseline regulatory standards to ensure that buildings are safe, healthy, energy efficient, and accessible for everyone who lives and works in and around them. The building control system then ensures that these standards are applied and enforced (Communities and Local Government, 2008).

This paper will present an analysis of the Portuguese building regulation system. The purpose here is to provide a general overview, highlight proposals for change, identify the main weaknesses, and suggest possible improvements. We have examined the main building regulations and the manner in which they are enforced. A review of the appraisals issued by professional associations within the construction sector was also carried out, in order to establish which themes are the subject of public debate. On the basis of the information collected, the main problems of the Portuguese building regulation system were identified and suggestions for improvements were put forward.

This research has been carried out as part of a European comparative research project currently underway at the OTB Research Institute for Housing, Urban and Mobility Studies (Meijer and Visscher, 2008). The project is divided into two phases. In the first phase (2007 and 2008), the aim is to describe the building regulation system in 35 European countries. For each country a monograph is being prepared which addresses the following subjects: the position of building regulations within the legislative system of the countries, the scope and contents of the building regulations that regulate the minimum level of quality for buildings, the building permit procedures, and the main features of the building control system. In the second phase (2009), a comparison of the information collected will make it possible to detect trends and developments taking place in the building regulation systems of the European countries.

Following this introductory section, the Portuguese building regulations are described in Section 2 and the building control system is presented in Section 3. Finally, in Section 4 an assessment of the system is presented and some practical recommendations about how to improve it are given.

\section{Building regulations}

\subsection{Organisation}

In Portugal there is no single Building Act which serves as a legal basis for building regulations and procedures, and defines the duties and responsibilities of the parties involved. The general building regulation is the main national building regulation, which sets out general provisions for building, regarding construction, health, safety, and aesthetics[1]. This regulation has been in force since 1951 and, despite several minor amendments, no fundamental revision has been approved. In addition, there are more than 45 national building regulations and other regulatory documents that focus on specific requirements. Almost all of these building regulations and regulatory documents were passed during the last two decades. Some of these building

[1] Decree-Law no. 38382 OJ (PT) August 7, 1951.

\section{Building regulation \\ system}

157 


\section{IJLBE 1,2}

158 regulations have been the consequence of implementing European Directives[2]. while others have been changed due to advances in the scientific knowledge.

In addition, there are other national regulations which set down provisions on construction and/or operational provisions for different types of buildings, which must be observed to ensure that the building can be used for the intended purpose. Social housing, nurseries, homes for the elderly and stadiums, for example, are required to meet specific building regulations.

There are no building regulations at the regional level within Portuguese continental territory. However, the two autonomous regions of Azores and Madeira can approve regional regulations and are also entitled to adapt the building regulations approved by Central Government to local circumstances. There are also municipal building regulations which complement national ones. These deal with subjects of municipal competence and local traditions and uses.

As a result, Portuguese building regulations are complex and fragmented. The Architects Association (2006a) described Portuguese building regulations as chaotic, claiming that they are scattered across about 1,000 legal documents. These characteristics make it difficult to have a comprehensive knowledge of the building regulations and to apply them. Architects and engineers are particularly concerned by this situation since they are responsible for ensuring that plans comply with building regulations.

The general consensus among politicians and technicians is that the general building regulation is outdated and needs urgent review (Engineers Association, 2006). However, the 2006 proposal to review this regulation was severely criticised by both architects' and engineers' associations. Rather than a simple review of the regulation, a complete reorganisation of the system was demanded. The Architects Association (2006a) recommended the following actions to improve building regulations: a single act should stipulate the key goals for construction, one coherent document should group together the main technical building regulations, and the general building regulation should be revised to fit into this model. After the negative reactions to the 2006 proposal, no further developments on this subject have come to public knowledge.

The state acknowledges the need to reorganise building regulations, since that is an objective expressed in law since 1999[3]. Given the impossibility of pursuing this objective immediately, the law has established that every year a ministerial order should be published with a list of the Portuguese legal provisions to be observed by the technicians responsible for developing and executing designs. This measure was intended to be provisional, but has been in force for almost ten years. According to the law, the municipalities must have available on their internet site an up-to-date list of the municipal regulations[4]. Successive governments did not engage in the intended

[2] Council Directive no. 95/16/EC of June 29 on the approximation of the laws of the Member States relating to lifts OJ L 213 of September 7, 1995, Council Directive 2002/49/EC of June 25 relating to the assessment and management of environmental noise OJ L 189/12 of July 18, 2002, Council Directive no. 2002/91/EC of December 16 on the energy performance of buildings OJ L 1/65 of January 4, 2003.

[3] Decree-Law no. 555/99 [legal framework for urban development and construction works] OJ (PT) December 16 with the amendments introduced by the Law no. 60/2007 OJ (PT) September 4, Art 123.

[4] Decree-Law no. 555/99 with amendments (n 3) Art 119. 
reorganisation of the building regulations, apparently because it is a long and complex technical process and there have been other political priorities.

\subsection{Formulation}

Some recently published building regulations are performance-based[5], but most existing ones adopt a prescriptive formulation[6]. More performance-based regulations are expected to be approved in the near future. For example, Eurocodes will replace the current building regulations on mechanical resistance and stability, and new fire safety regulations will replace the several separate regulations in this area. There is no official supporting documentation explaining the regulations in general terms. The national standards are not part of the building regulations and are not accessible free of charge. Some building regulations make direct reference to specific national standards that are mandatory, but even these mandatory national standards are not accessible free of charge. A Resolution of the Council of Ministers states that, whenever possible, building regulations should establish general principles and standards should include detailed information[7]. However, these guidelines have not been followed in recently approved regulations. The last proposal to review the general building regulation, for example, was criticised for being too detailed and prescriptive (Architects Association, 2006a; Engineers Association, 2006).

\subsection{Authorities responsible}

The fragmentation of building regulations is due to several reasons. One of them is that each ministry takes the initiative to develop national building regulations within its area of responsibility, whether separately or with other ministries. The Ministry for Public Works, Transport and Communications and the Ministry of Economy were involved in the preparation of most of the national building regulations. However, several other ministries have also participated in the preparation of national building regulations. Another reason for the fragmentation is that regional regulations are approved by the regional assemblies, and municipal regulations are approved by the municipal councils[8]. Such locally applicable regulations are subject to a period of public discussion before their approval, but not to review or approval by the national authorities. The fragmentation of the building regulations occurred although most of the national building regulations, with the exception of those on building services (e.g. water supply and sewage systems, electrical, and gas services), were drawn up under the supervision of the High Council for Public Works, Transports and Communications until 2007. In 2007, this High Council was abolished and part of its authority regarding building regulations was passed to the Institute for Construction and Real Estate (InCI)[9].

The assessment is that, during recent years, the approval of several new building regulations by various authorities has prevented any improvement of the organisation

[5] Law no. 80/2006 [regulation of the thermal behaviour characteristics of buildings] OJ (PT) April 4, Decree-law no. 9/2007 [general regulation on noise] OJ (PT) February 17.

[6] Decree-Law no. 38382 (n 1).

[7] Resolution of the Council of Ministries no. 91/86 [technical characteristics of the products new approach regarding technical harmonisation and normalisation] OJ (PT) December 26.

[8] Decree-Law no. 555/99 with amendments (n 3) Art 3.

[9] Decree-Law no. 144/2007 [approves the Organic Law of InCi] OJ (PT) April 27, Art 3. 


\section{IJLBE 1,2}

and compatibility of building regulations. For the future, there is a general understanding that an effort should be made to improve the system, but it is difficult to predict when that development may occur. In fact, there is a possibility that the status quo will simply be maintained due to the reduced of activity by the InCI in this field, and the attribution of regulatory authority to several authorities dependent on different ministries (Paiva, 2007). Governmental proposals to review the building regulations have been the target of repeated criticism (Ad Urbem, 2007; Architects Association, 2006a, 2007b). This criticism includes the fact that no studies of the construction sector have been presented to justify the changes, that the proposals have been developed without the participation of important stakeholders from the construction sector, and that the proposals have only been unveiled shortly before their approval, providing little opportunity for public debate and improvement. As a consequence, the approval of some proposals has been postponed indefinitely, while other proposals which have been approved have run into difficulties when applied and have needed extensive amendment. The Architects Association (2006a) is of the opinion that the main building regulations should be developed by a platform open to all stakeholders in the construction sector and that ways should be found to ensure that citizens participate effectively in public debate.

\subsection{Requirements for existing buildings}

Construction works carried out in buildings constructed under a previous regulatory framework do not have to comply with supervening building regulations. This means that a building permit or a building notice for reconstruction or alteration works on existing buildings cannot be denied on the basis of regulations approved after the original construction, provided the works do not create or aggravate non-compliances with current regulations[10]. This general principle is not observed in cases where the supervening regulations explicitly include existing buildings in their scope; in fact, this only happens in exceptional situations such as to ensure minimum levels of safety[11], comfort[12], or accessibility[13].

There are no building regulations which apply specifically to construction works in existing buildings. The only exception are the buildings located in urban areas developed without a planning permit. For the reconversion of these buildings there are minimum conditions of habitability that derogate certain specifications of the general building regulation[14]. As a consequence, there is no organised set of legal requirements for construction works on existing buildings. Yet the renovation of the building stock is presently one of the government's priorities to improve citizens'

[10] Decree-Law no. 555/99 with amendments (n 3) Art 60.

[11] Decree-Law no. 521/99 [standards for design of gas services to include in construction, enlargement or reconstruction designs of buildings, and regimen applicable to services inspection] OJ (PT) December 10, Art 13.

[12] Decree-Law no. 78/2006 [national system of energy certification and indoor air quality in buildings] OJ (PT) April 4, Art 3.

[13] Decree-Law no. 163/2006 [technical standards of accessibility to buildings and establishments receiving public, public ways and residential buildings] OJ (PT) August 8, Art 9.

[14] Decree-Law no. 243/84 [minimal habitability conditions for illegal construction] OJ (PT) April 17. 
quality of life (Presidency of the Council of Ministries, 2005). The extent of the building stock that fails to meet today's habitability conditions is considerable, since approximately 25 percent of the buildings were built before the general building regulation were passed in 1951 (INE, 2001). To require the renovation of old buildings to comply with present building regulations would be impractical or require extensive demolition and reconstruction. However, minimum habitability conditions must be guaranteed in all buildings, especially when renovation works are carried out, and this demands defining absolute minimum habitability requirements.

\section{Building control system}

\subsection{Development}

Today's building control system has evolved, driven by the need to adapt to the most pressing circumstances of practice, rather than based on a carefully designed and discussed overall plan.

In the 1970s, approving plans was frequently an excessively lengthy process because in some municipalities there was a lack of qualified municipal technicians to cope with the number of applications. In addition, the technical verification of a design implied that design responsibility was transferred or extended from the designer to the entity or technician that approved the design. The solution adopted by the law was to reduce municipal control during plan approval and to make designers responsible for complying with building regulations[15]. Municipal control was exerted during construction by means of regular site inspections or before issuing the occupancy permit. The legal framework for construction works of 1991 aimed at simplifying the building permit procedure[16]. This framework made it possible to submit a voluntary pre-consultation, it introduced a system for certifying that the design complied with building regulations by using private building inspectors[17], and it required designers and contractors to take out professional liability insurance[18]. However, in reality the last two changes were never actually put into practice.

Eight years later, a new legal framework for construction works was approved with the aim of simplifying the building permit procedure even further[19]. The main changes were the creation of a building notice procedure and the possibility of issuing a partial building permit for the construction of the structure before the final plan had been approved. At least one site inspection was mandatory for all construction works before the occupancy permit could be issued. The roles and responsibilities of the parties remained unchanged. In 2007, significant amendments were introduced

[15] Decree-Law no. 166/70 [legal framework for building permit procedure of private construction works] OJ (PT) April 15.

[16] Decree-Law no. 445/91 [amendment of legal framework for building permit procedures of private construction works] OJ (PT) November 20.

[17] Decree-Law no. 83/94 [certificate of design conformity for construction works that require plan approval] OJ (PT) March 14.

[18] Regulatory Decree no. 11/92 [liability insurance for designers in building permit procedures of private construction works] OJ (PT) May 16.

[19] Decree-Law no. 555/99 [legal framework for urban development and construction works] OJ (PT) December 16. 


\section{IJLBE 1,2}

162 to the 1999 legal framework[20]. Private building inspectors and designers were made responsible for assuring that construction works complied with building regulations and approved designs. The obligation for municipalities to carry out at least on site inspection was lifted and the sanctions for non-compliance were increased.

The building permit procedures described in this section apply to private construction works. Construction works undertaken by public authorities are exempt from building permit procedures[21]. There are also special legal frameworks for private construction works that apply to: the reconversion process of illegal urban areas[22], and the urban rehabilitation of historical areas and critical areas of urban recuperation and reconversion[23].

\subsection{Types of procedures}

According to their category, construction works can be exempted from building permit procedures, require a building notice or go through the regular procedure. Construction works include the construction, reconstruction, enlargement, modification, or maintenance of a building for human use or any other permanent fixed construction. The following types of construction activity are exempt from building permit procedures: maintenance inside buildings or their fractions (without modifying the structure, façade or roof), works with little urban relevance, and works promoted by public authorities[24].

The building notice applies to: reconstruction with the preservation of the facades; new construction, modification, or enlargement works inside an area with a local development plan or a consolidated urban area; swimming pools related to a main building; and changes in building use[25]. In a building notice procedure, an authorisation is given after the administrative aspects of the notification and the technical aspects of architectural design have been checked. The regular procedure applies to the remaining construction work, as well as all interventions on listed buildings or within their protection zones[26]. In this procedure a building permit is issued after the administrative aspects of the application and the technical aspects of architectural design have been checked. The submission demands and plan approval are similar for the building notice and the regular procedure. However, the maximum time for the building notice is shorter since it only applies in areas where detailed construction parameters have already been established in planning instruments.

During recent years, the trend has been to shift some types of building works from the regular procedure to the building notice, and from the building notice to exemption from building permit procedure. However, the exemption of some construction works has not been consensual. For instance, the Portuguese Federation of the Construction

[20] Law no. 60/2007 [sixth amendment to the Decree-Law no. 555/99, December 16] OJ (PT) September 4.

[21] Decree-Law no. 555/99 with amendments (n 3) Art 6, 6-A.

[22] Law no. 11/95 [special regimen for reconversion processes of illegal urban areas] OJ (PT) September 2.

[23] Law no. 104/2004 [special regimen for urban rehabilitation of historical areas and critical areas of urban recuperation and reconversion regime] OJ (PT) May 7.

[24] Decree-Law no. 555/99 with amendments (n 3) Art 6, 6-A, 7.

[25] Decree-Law no. 555/99 with amendments (n 3) Art 6.

[26] Decree-Law no. 555/99 with amendments (n 3) Art 4. 
Industry (2008) asked the legislator to reconsider the exemption of changes inside the buildings or their fractions. The federation believed that there was the risk of construction works being carried out without technical support from designers and by contractors without adequate qualification. The Architects Association (2007b) believes that the simplification of the building permit procedure could lead to the deregulation of the system, if it is not accompanied by an increase in responsibility of technicians.

As listed above, construction works undertaken by public authorities (central administration of the state, municipalities, public institutes, and public enterprises) are exempt from following the building permit procedures[27]. A building permit is not required, since each authority is responsible for assuring that its construction works comply with the building regulations. These construction works are usually carried out with public funds and serve the community or public interest. This implies that they ought to be the subject of public discussion and scrutiny. Furthermore, as in private building works, neighbours or other affected parties ought to be able to lodge objections. The Architects Association (2007b) therefore believes that the buildings promoted by these authorities should follow the same procedures as private building works.

\subsection{Design}

For private construction works, the phases and payment to develop a design depend on agreements made between developer and designer. The law makes no provisions in these areas, but those used in the design of public construction works usually serve as a reference. The absence of rules is understandable since this concerns a private agreement between developer and designer. This absence is partially replaced by statutory submission demands for the application to a building permit[28]. Requirements regarding the qualifications of designers were established 35 years ago[29]. Two important factors affected the definition of these requirements (Engineers Association, 2004): the small number of architects and engineers, and the common practice of having designs developed by other less qualified technicians. As a consequence, the specialisation and level of qualification required was not high. For instance, architectural designs can be signed by architects, civil engineers, or civil and mining technical engineers. Contractors with professional technical education can also sign simple architectural designs. The socio-economic framework has changed significantly since the approval of the law. This change has had considerable influence on the nature and level of the education of the technicians qualified to design: new degrees have been created (e.g. landscape architecture) and there has been a significant increase in the number of architects and engineers (Engineers Association, 2004; Architects Association, 2005).

There is a general consensus among the professionals that the law on the requirements of designer's qualifications should be changed. The Engineers Association (2004) presented a draft for a new law on this subject, and the Architects

[27] Decree-Law no. 555/99 with amendments (n 3) Art 7.

[28] Ministerial Order no. 232/2008 [submission demands for requests to carry out construction works foreseen in Law 60/2007, of September 4] OJ (PT) 11 March.

[29] Decree no. 73/73 [qualification of the technicians responsible for designs of construction works submitted for plan approval] OJ (PT) February 28.

\section{Building regulation \\ system}

163 


\section{IJLBE 1,2}

164
Association (2005) submitted a petition signed by more than 35,000 citizens to Parliament, with the aim of revoking the current law. In response to the increasing inadequacy of the existing law and the initiatives of the professional associations, the government prepared a proposal of law[30]. This proposal defines the qualifications, duties and responsibilities for designers and technicians that inspect and manage construction works. The proposal of law received an unenthusiastic reception from several associations (National Association of Technical Engineers, 2007; Ad Urbem, 2007; Architects Associations, 2007a; SATAE, 2007). The main ground for dissatisfaction was that it limited the area of intervention of some professional corporations. Approval of the proposal of law was suspended and in 2008 a working group was created in Parliament to study this subject.

\subsection{Pre-consultation}

Before a design is submitted, the applicant may voluntarily ask the municipality for a pre-consultation. During pre-consultations, the tasks and responsibilities of the parties involved are discussed, as well as planning aspects[31]. For small construction works, a formal pre-consultation is usually replaced by a meeting between the applicant and municipal representatives. Someone other than the owner of a land parcel may also request a pre-consultation[31]. In such cases, the municipality notifies the owner and other persons with legal rights over the land parcel. External authorities can be consulted during this phase[32]. Their appraisals remain valid for a period of one year, making new consultation in later stages of the procedure unnecessary. If the result of the pre-consultations is unfavourable, the applicant must be informed about how to modify the proposal in such a way as to comply with the planning requirements[33].

\subsection{Submission}

There are nationally applicable statutory submission demands to apply for a building permit[34]. The municipalities can add to this list of demands. For each building permit procedure, a manager in the municipality accompanies the procedure from start to finish and is responsible for guaranteeing its normal progress[35]. Electronic handling has been introduced to varying degrees in different municipalities. In almost all municipalities it is possible to download information and paper forms. Some major municipalities already accept applications to be submitted electronically and to track progress during plan approval. A system to handle the building permit procedures electronically is being developed[36].

[30] Proposal of Law no. 116/X/2 [professional qualification required to technicians responsible for developing and signing designs, inspections of construction works and management of construction works] February.

[31] Decree-Law no. 555/99 with amendments (n 3) Art 14.

[32] Decree-Law no. 555/99 with amendments (n 3) Art 15.

[33] Decree-Law no. 555/99 with amendments (n 3) Art 16.

[34] Ministerial Order no. 232/2008 (n 28).

[35] Decree-Law no. 555/99 with amendments (n 3) Art 8.

[36] Decree-Law no. 555/99 with amendments (n 3) Art 8-A, Ministerial Order 216-A/2008 [regulation of the operation of the informatics' system foreseen in Law no. 60/2007, of September 4] OJ (PT) March 3. 
3.6 Plan approval

The approval of plans within the regular building permit procedure is divided into two phases[37]. In the first phase, the municipality verifies the administrative aspects of the application and assesses whether the architectural design complies with urban development plans and building regulations. After the approval of the architectural design, engineering designs are submitted. In this second phase, the municipality makes an administrative check of the engineering designs. Depending on the type of building and its location, other authorities are also consulted in connection with the approval of the architectural and the engineering designs. The authorities that are consulted fall into four main groups depending on their tasks: those authorities that manage the protection areas of listed buildings, collective facilities, or environmental heritage; those that supervise the use of certain types of buildings; those that provide urban services; and those that guarantee health and safety. Each of these authorities examines the aspects that lie within their own remit. Their appraisals are mandatory if the law establishes it and if the arguments are based on legal requirements. The developer can also ask the relevant authorities directly for the approval of the design and submit those approvals together with the application for the building permit[38].

Once all approvals from other authorities have been granted, a final decision is taken by the municipality[39]. A favourable decision will lose its validity if the developer fails to request the building permit certificate within one year after the notification. There are statutory demands on how to request the building permit certificate[40], and for the content of the certificate[41]. In a building notice, the plan approval procedure is similar to the one described for the regular procedure. However, it is not divided into phases and a detailed design in not required.

The compliance of each design with the relevant building regulations and planning requirements is attested to by liability declarations of the designers[42]. The compatibility between designs is attested by a liability declaration of the design coordinator. If it is not possible to comply with all building regulations, designers must also declare which provisions have not been met and provide explanation. In such cases, those parts of the design that do not comply with building regulations are thoroughly checked by the municipality to confirm the designers' justifications. This situation applies particularly to construction works carried out within existing buildings, which do not have to comply with supervening regulatory requirements.

After the building permit has been issued and the construction works has begun, a copy of the detailed design (detailed architectural and engineering designs) must be submitted to the municipality[43]. This means that a poorly developed detailed design can be submitted, simply as a means of satisfying the administrative requirement for

[37] Decree-Law no. 555/99 with amendments (n 3) Art 20.

[38] Decree-Law no. 555/99 with amendments (n 3) Art 13.

[39] Decree-Law no. 555/99 with amendments (n 3) Art 26.

[40] Decree-Law no. 555/99 with amendments (n 3) Art 71.2, 76.1, Ministerial Order no. 216-E/2008 [submission demands to requests certificates for urban development and construction works] OJ (PT) March 3.

[41] Decree-Law no. 555/99 with amendments (n 3) Art 77.4, Ministerial Order no. 216-D/2008 [models of certificates for urban development and construction works] OJ (PT) March 3.

[42] Decree-Law no. 555/99 with amendments (n 3) Art 10.

[43] Decree-Law no. 555/99 with amendments (n 3) Art 80.4.

\section{Building regulation \\ system}

165 


\section{IJLBE 1,2}

166 a detailed design. The Architects Association (2007a) pointed out that the detailed design was an essential element to ensure the quality of the building work. If the design is not developed until that phase, there is not enough information for the designer to assure compliance with building regulations. Furthermore, the detailed design is also an important way for contractors to manage the construction process, for insurance companies to determine the risk of the investment, and for municipalities to inspect construction works. The Architects Association (2006b) considers that a certification system by private building inspectors of designs to ensure compliance with building regulations and planning requirements, similar to the one that failed to be implemented in the 1990s, should be resumed. The Engineers Association (2004) has suggested the creation of a construction commission to keep a national registry of designs (including the formation of the team) and verify, through spot-checks, the conformity of liability declarations.

\subsection{Objections to construction works}

A general announcement must be posted at the construction site, visible to the public, within ten days after the application for a building permit or the notification of the building notice[44]. An announcement must also be posted at the construction site within ten days after a building permit is obtained[45]. This announcement must remain visible until the end of the construction works. Both announcements must follow standardised formats established by law[46]. Other parties can object to planned construction works. During plan approval objections are taken into consideration. After the plan has been approved, if other parties consider that their objections were not properly considered, they can make a legal appeal. During construction, other parties can also object to works viewed as being in non-compliance with approved design or building regulations, and ask for a municipal site inspection.

\subsection{Commencing the construction work}

The construction work can start after a building permit certificate or an authorisation to a building notice has been obtained[47]. There are two exceptions to this. First, a partial building permit can be issued for the construction of the structure immediately after the delivery of the engineering designs[48]. Second, the demolition or excavation and peripheral containment of the soil until the level of the lower floor is permitted after the application for a building permit[49]. The developer has until five days before the start of the construction work to inform the municipality of his intentions, as well as the identity of the technical director responsible for the work[50].

[44] Decree-Law no. 555/99 with amendments (n 3) Art 12.

[45] Decree-Law no. 555/99 with amendments (n 3) Art 61.

[46] Ministerial Order no. 216-C/2008 [models for announcement of applications to carry out construction operations] OJ (PT) March 3, Ministerial Order no. 216-F/2008 [models for announcement of titles to carry out construction operations] OJ (PT) March 3.

[47] Decree-Law no. 555/99 with amendments (n 3) Art 80.

[48] Decree-Law no. 555/99 with amendments (n 3) Art 23.

[49] Decree-Law no. 555/99 with amendments (n 3) Art 81.

[50] Decree-Law no. 555/99 with amendments (n 3) Art 80-A. 


\subsection{Quality control}

Quality control during the construction work is assured by the following parties: a private building inspector, selected by the developer, who guarantees compliance with the approved design; and a technical director, who is an employee of the contractor responsible for the construction works. The developer can appoint a design coordinator to give technical assistance in the contest to select the contractor and during construction[51]. There must be a construction log book at the building site[52]. In this book the technical director records relevant facts about the construction works, such as the beginning, suspension and conclusion of works, as well as modifications made to the approved design. The private building inspector and the design coordinator also register their participation in the construction log book. The format of the log book is established by law[53]. There are two special systems of building control: the certification of gas services[54], and the certification of energy performance and indoor air quality of buildings[55]. In these systems, the compliance of the design and construction work with the building regulations is checked by specialised private building inspectors accredited by the state.

\subsection{Site inspections}

Site inspections are not mandatory. The municipality may carry out site inspections irrespective of the type of procedure[56]. Site inspections are carried out randomly and without notifying the developer beforehand. All aspects of the construction works can be checked during inspections, including the construction log book. Depending on the location and type of the building, other authorities may have specific inspection responsibilities. Building works about which complaints have been made are more likely to undergo a site inspection by municipal building inspectors. It is foreseen by law that the municipality can appoint private building inspectors to carry out site inspections[57]. Until now, the duties, responsibilities and guarantees of private building inspectors have not been regulated and consequently it is not possible to appoint them yet. The municipality has the legal power to stop the construction works which are being carried out without a building permit or a building notice, which do not conform to the approved design, or are in violation of building regulations[58].

\subsection{Completion}

Prior to occupation, an occupancy permit certificate must be obtained[59]. There is a statutory list of submission demands, set at national level, to request an occupancy

[51] Decree-Law no. 555/99 with amendments (n 3) Art 63.

[52] Decree-Law no. 555/99 with amendments (n 3) Art 97.

[53] Ministerial Order no. 1109/2001 [model of the construction log book] OJ (PT) September 19.

[54] Decree-Law no. 521/99 [standards for design of gas services to include in construction, enlargement or reconstruction designs of buildings, and regimen applicable to services inspection] OJ (PT) December 10.

[55] Decree-Law no. 78/2006 [national system of energy certification and indoor air quality in buildings] OJ (PT) April 4.

[56] Decree-Law no. 555/99 with amendments (n 3) Art 93.

[57] Decree-Law no. 555/99 with amendments (n 3) Art 94.

[58] Decree-Law no. 555/99 with amendments (n 3) Art 102.

[59] Decree-Law no. 555/99 with amendments (n 3) Art 4.4.

\section{Building regulation \\ system}

167 


\section{IJLBE 1,2}

168 permit, which can be complemented by the municipalities[35]. This list includes the design with the work actually carried out, the construction log book, and liability declarations by the design coordinator and the private building inspector[52]. In these declarations, the signatories state that the construction works were carried out according to the approved design, and, where applicable, changes comply with the relevant legal and regulatory requirements. The occupancy permit is granted by the municipality on the basis of the liability declarations mentioned above[60]. No site inspection is required. The municipality can decide to carry out an inspection if there are doubts about whether the construction works comply with the approved design.

Once the occupancy permit has been granted, the developer has one year to request the certificate[61]. There are statutory requirements for applying for the occupancy permit certificate[62], and for the content of the certificate[63].

\subsection{Procedure times}

For a pre-consultation, the maximum duration of the procedure is 20 days if the process does not require the consultation of external authorities and 70 days if such consultation is required[40]. For a building notice, the procedure may take up to 20 and 60 days, respectively, for the same situations[64]. If the maximum procedure time for a building notice expires without a rejection, it is assumed that it has been accepted[65]. For a regular procedure, the maximum procedure time is 185 days for standard construction works and 225 days for construction works carried out on listed buildings[49]. If the maximum procedure time expires without a municipal deliberation, the developer can appeal to court[66]. After deliberation, the developer requests the building permit certificate and the municipality has 30 days to issue it[67].

\subsection{Fees}

The fees are determined by each municipality according to general principles defined in a national decree[48]. The level of the fees is determined based on the floor area, the type of construction, and the location. A fixed level for procedural analysis is usually set. Usually, the fees are paid at the following moments of the process: on submitting an application, on obtaining the building permit certificate, and on obtaining the occupancy permit certificate. If the building is located in an area without an approved local development plan or has an impact identical to a local development plan, an additional urban development municipal fee must be paid to obtain the building permit[68]. This fee is to cover the expenses on building, reinforcement and maintaining infrastructures.

[60] Decree-Law no. 555/99 with amendments (n 3) Art 64.

[61] Decree-Law no. 555/99 with amendments (n 3) Art 76.1.

[62] Decree-Law no. 555/99 with amendments (n 3) Art 76.1, Ministerial Order no. 216-E/2008 (n 41).

[63] Decree-Law no. 555/99 with amendments (n 3) Art 76.6, 77.5, 77.6, Ministerial Order no. 216-D/2008 (n 42).

[64] Decree-Law no. 555/99 with amendments (n 3) Art 36.

[65] Decree-Law no. 555/99 with amendments (n 3) Art 36-A.

[66] Decree-Law no. 555/99 with amendments (n 3) Art 112.

[67] Decree-Law no. 555/99 with amendments (n 3) Art 76.4.

[68] Decree-Law no. 555/99 with amendments (n 3) Art 116. 


\subsection{Sanctions}

If municipalities detect any irregularities in liability declarations, they must inform the professional associations. The technicians that signed those liability declarations may be subjected to a disciplinary procedure by their professional associations. If the gravity of the infraction justifies it, municipalities can ban the technician from working in its territory for a period of up to four years[69]. The increase in sanctions for false declarations was one of the changes included in the 2007 amendment of the legal framework for construction works[70]. This change was presented as a way to increase the responsibility of technicians. The Architects Association (2007b) proposed a clearer definition of duties and responsibilities instead of an increase in sanctions.

\section{Discussion}

There has been a positive evolution in the building regulations. All main requirements are addressed by building regulations approved in the last two decades. The recent building regulations adopt a performance-based formulation. The revision of some main building regulations is underway and harmonized European Standards are being adopted as national standards. Most municipalities also have up-to-date municipal building regulations. Despite this evolution, one main problem persists: building regulations are complex and fragmented, making it difficult to apply them comprehensively. Other problems include the lack of building regulations specific for existing buildings, an impasse in the process to review the general building regulation, the granting of regulatory authority to several authorities dependent on different ministries, and the limited participation and debate of proposals to review the building regulations.

The building control system has also changed significantly over recent years. The simplification of the building permit procedure and the reduction in the procedure time were the main aims that guided this change. Several procedural modifications were introduced: a building notice was created, municipal control over some types of construction works was decreased, voluntary pre-consultation became possible, the issue of a partial building permit was allowed, statutory submission demands were established, procedure times were shortened and the online handling of procedures is being implemented. Besides, these procedural modifications, the roles of the parties involved also changed. The responsibility for verifying that the plan complies with building regulations and controlling construction works has shifted from municipalities to private parties. Municipalities are still responsible for granting building and occupancy permits, but aside from that they have taken mainly a supervisory role.

There is one important reform necessary, the lack of which is undermining the building control system. The qualifications, duties and responsibilities of technicians involved in construction works are not clearly defined. Furthermore, although technicians take responsibility for their actions, professional liability insurance is not mandatory. A proposal of law establishing these requirements is being prepared, but a delicate balance between the interests of professional corporations is necessary and this has not yet been reached.

[69] Decree-Law no. 555/99 with amendments (n 3) Art 99.

[70] Law no. 60/2007 (n 20).

\section{Building regulation \\ system}

169 


\section{IJLBE 1,2}

On the basis of the proposals put forward by professional associations and the knowledge acquired in previous and ongoing European comparative research projects (Meijer et al., 2002), some suggestions can be put forward to improve the Portuguese building regulations system. Regarding the building regulations, a single act should set out the key goals of construction work, one coherent document should group all the main technical building regulations together, performance formulation should be adopted, detailed technical information should be incorporated in standards, and minimum habitability requirements for renovation work on existing buildings should be defined. As far as the building control system is concerned, only qualified professionals should be able to operate within the system, the responsibilities and duties of professionals should be clearly defined, a detailed design should be mandatory to obtain a building permit, and the certification of design compliance with building regulations by private building inspectors should be required for large-scale construction works.

In order to achieve these reforms, a detailed study of how the present Portuguese system is working should be undertaken. The building regulation systems of other countries should also be considered by decision makers, since much can be learned from their experience. Once the legislator has defined the overall model, a debate should be held with stakeholders. This debate should provide the basis to establish a permanent platform open to all stakeholders in the construction sector where reforms of the system can be discussed.

\section{References}

Ad Urbem (2007), Appraisal of the Proposal of Law 116/X/2, AD URBEM, Lisbon, available at: www.adurbem.pt/images/stories/ficheiros/actividades/Parecer_Ad_Urbem_116_X.pdf (accessed June 16, 2008) (in Portuguese).

Architects Association (2005), The Right to Architecture. Revoke Decree 73/73, Architects Association, Lisbon, available at: http://arquitectos.pt/documentos/1183743491G7e EF1tm1Ep05FZ4.pdf (accessed June 16, 2008) (in Portuguese).

Architects Association (2006a), Appraisal About the Pre-project to Review the General Building Regulation, Architects Association, Lisbon, available at: www.oasrn.org/pdf_upload/ Revisao\%20RGEU\%20-\%20parecer\%20aprovado\%20CDN.pdf (accessed June 16, 2008) (in Portuguese).

Architects Association (2006b), Appraisal of the Architects Association About the Proposal to Review the Decree 73/37, of 28 February, paper presented by IMOPPI and dated 17 November, Architects Association, Lisbon, available at: http://arquitectos.pt/docume ntos/1164243599V2tZX0fj0S175TM3.pdf (accessed June 16, 2008) (in Portuguese).

Architects Association (2007a), Appraisal about the Proposal of Law 116/X/2, paper presented by the Government, Architects Association, Lisbon (in Portuguese).

Architects Association (2007b), Appraisal about the Proposal to Review the Decree-Law No. 555/99, of 12 December, paper presented by the Secretary of State Assistant and for Local Administration, with the date 21 May, 2007, Architects Association, Lisbon, available at: http://arquitectos.pt/documentos/1182847778T1eVD6uc1It23JC2.pdf (accessed June 16, 2008) (in Portuguese).

Communities and Local Government (2008), The Future of Building Control. Consultation, CLG, London, available at: www.communities.gov.uk (accessed June 16, 2008). 
Engineers Association (2004), Proposal to Review the Decree 73/73, of 28 February, Engineers Association, Lisbon, available at: www.ordemengenheiros.pt/Default.aspx?tabid $=356$ (accessed June 16, 2008) (in Portuguese).

Engineers Association (2006), Appraisal of the Engineers Association about the Project to Review the General Building Regulation with the Date of May 2006, Engineers Association, Lisbon, available at: www.ordemengenheiros.pt/LinkClick.aspx?link=Parecer-RGEParecer $+\mathrm{da}+$ Ordem.doc\&mid $=773$ (accessed June 16, 2008) (in Portuguese).

\section{Building regulation system}

INE, Statistics Portugal (2001), "Buildings by location and construction period", available at: www.ine.pt/xportal/xmain? $x p i d=I N E \& x p g i d=$ ine_indicadores\& indOcorrCod $=0000727 \&$ selTab $=$ tab2 (accessed June 16,2008 ) (in Portuguese).

Meijer, F. and Visscher, H. (2008), "Building regulations from an European perspective", Proceedings of COBRA 2008 - The Construction and Building Research Conference of the Royal Institution of Chartered Surveyors, RICS, London.

Meijer, F., Visscher, H. and Sheridan, L. (2002), Building Regulations in Europe, Part I, A Comparison of the Systems of Building Control in Eight European Countries, Delft University Press, Delft.

National Association of Technical Engineers (2007), Letter to the President of the Parliament About the Public Discussion of the Proposal of Law 116/X/2, about the Revocation/Replacement of the Decree 73/73, of 28 February, ANET, Lisbon, available at: www.anet.pt/site/index.php?option $=$ com_content\&task $=$ view\&id $=89 \& I t e m i d=$ 2 (accessed June 16, 2008) (in Portuguese).

Paiva, J. (2007), Importance of the Normative Framework and Regulatory in the Sector of Construction and Public Works, LNEC, Lisbon (in Portuguese).

Portuguese Federation of the Construction Industry (2008), "FEPICOP contests exemption of building permit for construction works inside the buildings", available at: http://preview.a neop.pt/noti.look? viewDataId $=1919 \&$ scctrl $=1 \&$ sclang $=3 \&$ scpm $=1$ (accessed June 16, 2008) (in Portuguese).

Presidency of the Council of Ministries (2005), "Program of the XVII Constitutional Government", available at: www.portugal.gov.pt/Portal/PT/Governos/Governos_Constitucionais/GC17/ Programa (accessed June 16, 2008) (in Portuguese).

Union of Agents with Technical Degree on Architecture or Engineer (2007), Appraisal of SATAE about the Proposal of Law 116/X, SATAE, Lisbon, available at: www.satae.com/website/ content/view/116/271/ (accessed June 16, 2008) (in Portuguese).

\section{Corresponding author}

João Branco Pedro can be contacted at: jpedro@lnec.pt

\footnotetext{
To purchase reprints of this article please e-mail: reprints@emeraldinsight.com
} Or visit our web site for further details: www.emeraldinsight.com/reprints 